\title{
Performance Appraisal in the Era of New Normal
}

\author{
Nitika Kaushik*, Poonam Arora \\ The North Cap University, Gurugram-122017, Haryana, India \\ E-mail: nitika90309@gmail.com*,poonamarora@ncuindia.edu
}

\section{ARTICLE INFORMATION}

Received: June 26, 2020

Revised: July 11, 2020

Accepted: July 24, 2020

Published online: July 31, 2020

Keywords:

Covid -19, Social distancing, Remote working, Performance appraisal

\begin{abstract}
Performance Appraisal is the process of assessing the accomplishments of workforce \& to acknowledge their capabilities for facilitating development. Performance evaluation is one of the areas in human resource management which is considerably affected by the spread of pandemic severe acute respiratory syndrome corona virus 2 . This virus outbreak posed new challenges for the companies across the globe. As a result in order to tackle this uncertainty various organizations have taken measures to cut down the expenses like deferment in the appraisal cycle or for muted salary increments. Thus one of the objectives of this paper is to study the impact of Covid -19 on performance appraisal of employees. Further this pandemic is equally challenging for the managers also. As social distancing and working remotely have become a new normal, employees work remotely from each other and from managers, and this will be more common in the future. Managers are now searching for new ways to 'do visibility' without always being physically present. It has also become the vital demand of the situation as managers must be aware of the circumstances in which employees are working in. Therefore another objective of this paper is to suggest an approach to manage the performance evaluations of remote working employees. It is recommended that managers should adopt the choice based approach for performance evaluation instead of control based approach. The review is formed on articles and reports from various internet sources and journals. Further some ways of managing the performance assessment of remotely working employees and scope for the future are also discussed.
\end{abstract}

\section{Introduction}

Covid-19 has a growing impact on the world economy. This disease continues to spread rapidly around the globe. In India also there is significant hike in the number of cases and in response it has evolved its action plan of making the nationwide lockdown resulting in slowdown in the nation's economy. This has a huge impact on the appraisal cycle of the employees. Appraisal of employee's performance is the one of the areas of human resource management where the organizations are taking tough decision to either delay or waive off the salary of all employees in an effort to decrease expenses and protect the future and thereby taking the chance of not compensating and incentivizing their employees well during the corona crisis. However at the same time it is very essential to increase the dedication and morale of employees in order to maintain the company stability and to win the battle with the impact of Corona virus.

With the recent Corona crisis, social distancing has become the new normal. Employees have started working from home, which in turn has a powerful impact on appraisal of 2020 employees. Manager and employees work remotely from each other. This creates the challenging task for managers as they want maximum productivity but due to social distancing there would be no close supervision of employees.

All this has created the demand for the new approach for the performance evaluation of employees. Managers have to shift their approach from trying to enforce every employee to work for the maximum of their limits, to the one with personalized choice board contracts for each employee; and pay accordingly (Forbes, 2020). With individualized performance based approach managers can pay to top performers much better than the rest of the employees and the other will not feel deceived as they will be compensated as per their own choice. Now the employees don't have to stress to stretch themselves beyond their wishes and can go to their job with less distress and more satisfaction. Further the later part of the paper highlights some of the ways that can be helpful for the managers in managing the remote working employees. Followed by the scope for the future and conclusion. 


\section{Literature Review}

As Covid-19 is expanding across the globe, people have started living through a time of uncertainty. Organizations are taking important steps, in order to maintain a healthy workforce (Balani, 2020). But there are many possibilities that companies are thinking of the traditional bonus payouts and planning for delays in paying variables by at least a quarter in order to tackle the performance appraisals in this tough economic situation (Chatterjee, 2020).

According to (Ghose, 2020), Deloitte India, Covid -19 has made a huge impact on companies financial plans. Experts told Economic Times that most manager will opt for stand by approach on variable compensation (Sarkar, 2020). Usretay (2020), director, Willis Towers Watson said that "Employers may make the decision for muted salary increases anticipating in this time of uncertainty". Many employers may defer hike by three month period and will keep monitoring the condition. Compensation experts said organizations may go for deferred salary hike and will be taking a decision once situation will become normal (Usretay, 2020).

However the turmoil produced by the corona crisis have led Reliance Industries (RIL) to execute salary reduction and delayed bonus for workers in the hydrocarbon business, at the same time the chairman of the organization Mukesh Ambani, will waive off his full salary, effective April 1, 2020 The Financial Express (2020).

Chairman of $\mathrm{PwC}$ India have taken vital steps in order to deal with this ambiguity which includes stay on promotions, salary hike and bonus of employees till the time the situation becomes more predictable for the business (Mukherjee, 2020).

KPMG spokesperson (2020) highlighted that audit firms are among the front-line organizations impacted by the corona crisis as most of their clients have ceased crucial projects. In India the senior partners of KPMG have opted to pass on their incentives and bonuses. "We will be in a better position to comment on this next week as we are still evaluating our options," said a KPMG spokesperson (2020).

Many Indian companies $\mathrm{PwC}$, Deloitte and EY have taken decision to delay their appraisal cycles, which includes delaying promotions and bonuses, due to the pandemic, as quoted by officials working with these firms (Upadhyay, 2020).

Partner at Deloitte India further quoted that virus outbreak has resulted in the rigidity in salary structure and planning will be done to make these more variable in the future (Ghose, 2020). Infosys and TCS also expect huge strike on its bottom line as businesses across multiple sectors are impacted by the exponential growth of the corona virus (Gill, 2020). The organization predicts its business to be impacted in all locations. (Roy, N., 2020), chief financial officer, Infosys, said the company has taken steps to cut costs amid of corona crisis. "We have also frozen any salary hikes, and temporarily suspended all promotions." Many organizations may give a nominal hike now and will make a further increase in future when the situation is more certain, said by the CEO of Aon (Sethi, 2020).

Balani, A. (2020) identified that in this period of slowdown and uncertainty the role human resource team of the organization becomes quite essential to provide guidance, build strategy and implement support to the employee's . This is the time to activate crisis management plan.

To reduce the spread of corona virus many organizations are opting for social distancing and switching to remote working (Verbeemen et al., 2020). However many companies oppose for managing the performance of remote employees (McIlvaine, 2020). According to them earlier everything were managed centrally but after covid outbreak everything need to organize remotely (Verbeemen et al., 2020). In most of the cases, the workforce is not well versed with working remotely. Also many employees will have kids and spouse at home. Work from home will blur the boundaries between work and private life. It will become a challenge to maintain the balance between work and private life. Due to crisis employees in any places will no longer have the option of working from their favorite coffee shop or the library as a place of respite.

Lewis, D. (2020) CEO of OperationsInc, identifies that managers must play a guiding role in helping employees get adapted to the new normal as best they can. According to him, managers are required to reset their expectations for productivity. Employers have to retain their best of the talent and also support their staff and ensure their job security (Mcllvaine, 2020). According to (Forbes, 2020), with current covid crisis the forced based distribution has to be changed to choice based distribution for performance and employees should be compensated accordingly. This is done to strike the balance between managing the costs and at the same time retaining the effective employees. Workforce should be provided flexibility and choice in their jobs (Mayer, 2020). In terms of productivity, whereas before, employees were expected to produce $\mathrm{X}$ number within eight hours, may be now it could be 12 hours says (Lewis, 2020).

\section{Research Method}

Secondary data were used in this research. Data was collected from past researches, books, internet and various research papers and articles published in journals.

\section{Research Objective}

(i) To study the impact of Covid-19 on performance appraisal of employees.

(ii) To suggest an approach to manage the performance evaluations of remote working employees. 


\section{Performance Choice Board (PCB)}

With recent Covid 19 crisis, working at home has become the new normal. Managers are increasingly concerned about losing their direct supervision on employees and find it challenging to assess their performance. At the same time, employees want liberty and flexibility in job according to their own personalized choice. As employees want more autonomy, supervisor want maximal yield and performance. It has created a situation in which for one team to win, the other must lose. But there can be plausible solution for this kind of situation.

It is formed on traditional Pareto (80:20) principle. According to this principle $80 \%$ of results are guaranteed by the top $20 \%$ exceptional employees. Virtual or in office, these 20\% employees are exceptional performers for whom work is everything. These live to work employees wants challenging environment. For them work is the prime concern. $60 \%$ employees are those for whom work and family both are equally important. These employees will choose to give great support for their job but at the same time they want some flexibility for other concerns also. Rests of the employees are work to live and will work just enough to preserve their job safe. For them work is essential just to pay the bills. Even if closely administered or not, performance in team of hundred or more takes a normal shaped distribution curve.

In order to deal with current covid pandemic effect the normal shaped distribution curve has to be changed to Performance Choice Board (PCB). "One size fits all” has to be replaced with individualized performance choice board agreements for all employees; and accordingly should be compensated. Supervisor can compensate their top performers much more as compare to other employees, and others will not feel deceived as they will be compensated according to their own contracts. Now the $60 \%$ of employees, who work and live both and $20 \%$ of employees, who work to live, can do their job with more satisfaction and less stress. There can be enhancement in the work performance of $80 \%$ employees as the stigma associated with job is being removed (as shown in Figure 1).
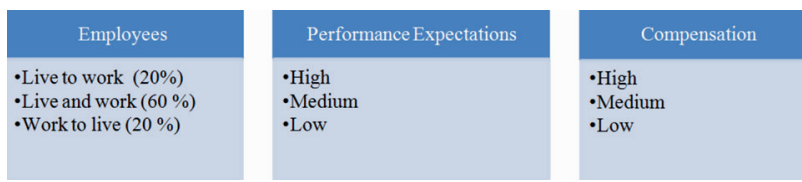

Figure 1: Categories of employees in performance choice board method Source: Formulated by author, based on literature

In this the most effective 20 percent employees or the top performers are accountable for eighty percent of the outcome. In this kind of work environment - virtual or in-office there will always be twenty percent of employees for whom work is the main priority, and they are capable of giving eighty percent of the outcome. So, eighty percent of company's result is assured.

\section{Managing a Virtual Workforce}

There are certain points which manager must consider in order to protect performance and productivity in a performance choice based management system:

(i) Precise Conversation: Managers should clearly communicate the performance expectations at the top twenty percent, the middle sixty percent and the last twenty percent of the performance choice based management system. Goals and objectives must be as assessable as possible.

(ii) Individualized Choice: Once the goals and objectives at each level are clear cut, then employees are asked to decide for the plan with complete knowledge of the reality that their remuneration will going to be equivalent with how they choose to work. Employees who are going for work-to-live contract should be informed explicitly that if their performance comes down the minimum expectation, then they will not be rewarded.

(iii) Resolving opinion differences: In case of a clash of viewpoint about performance, the supervisor's say will be conclusive. If employees demands flexibility, there is the cost that need to pay. Supervisor should try his best that such clashes do not occur.

(iv) Stay in constant touch: Managers must be available to assist employees who need and ask for support. Use instant messaging to employees in order to stay in regular touch. They should conduct one to one progress review discussions at least once in 30 days. Be a mentor as required.

(v) Open about pay: Remuneration should be as clear as possible. In a Performance Choice Based management system, it is not required to be quiet about remuneration. Supervisor can justify that compensation is equivalent to individual choices.

(iv) Providing Flexibility: Employees should be given flexibility to opt for either at higher level or lower level. There should be not be any stigma associated with the level chosen by the employees. Contribution of employees at all level is vital to complete the picture.

\section{Recommendations}

With the onset of pandemic, the question arises of managing remote working employees. If companies have largely remote workforce, close supervision will be a challenging task for managers. There are certain recommendations for the managers in order to deal with performance appraisals and its impact on compensation and retention of effective employees and the overall morale of employees.

(i) Redefining expectations:

Managers should redefine their expectations for how to get the job done. There should not be any strict 
boundaries for accomplishing the tasks. Managers should provide flexibility to the employees to complete the tasks and should focus on the end results

(ii) Boosting the employee morale :

Managers should be effective in building the employee morale. Shorter communication cycle times helps in sustaining the employee engagement.

(iii) Use of continuous and micro learning:

During the covid crisis where remote working has become the new normal learning should not stop. Use of micro learning is more beneficial in this new environment. There should be focus on giving short lessons on a single topic in a five to ten minute segment. Employees should be allowed to identify their own topics for training.

(iv) Shared Leadership :

Assign buddies and peer coaches to provide mutual support to employees. This will prevent the managers from getting exhausted by attending the queries of all team members. Employees could be organized into pairs and a buddy or a peer coach can be assigned to them. In this way responsibility can be shared among the employees.

(v) Interpreting tone and voice as representative of direct feedback :

It is difficult to understand the emotional cues of remote working employees in comparison to the one when manager and employees work in same room. Manager must understand proxy indicators such as tone and voice of employees in video communication. If manager knows his employees, changes in these patterns will help him find out promptly that an employee needs some additional support.

\section{Limitations and Scope for Future Research}

(i) This study is based on secondary data, more methods of data collection can be explored for future research.

(ii) The current study can be extended for comparison between performance evaluation of remote working employees and employees working within organizations.

\section{Conclusion}

It is clear that at this time of uncertainty there would be some deep and perhaps long lasting impact to our work practices. As pandemic hitting the globe from various directions, companies are exposed to new challenges like shutting down the offices and reducing the business operations. Due to this many renowned organizations have taken the decisions to either defer the appraisal cycle or go for muted salary increments or opting for working remotely. However many managers are arguing against managing a largely remote workforce. According to them if large numbers of workers are working remotely, close supervision is not even an option. Managers are concerned about the productivity therefore as an alternative to this situation they are looking for new ways of assessing the performance of employees. This is done to retain the effective employees and to maintain the balance between private and work life of the employees, which is very essential to this time of crisis. As it turns out, giving freedom is a good thing. Therefore performance choice based approach is being recommended to the managers. Thus this paper highlighted the impact of novel corona virus on performance appraisal of employees and suggested managers performance management approach to manage the performance assessment of employees. As there is so much uncertainty about how 2020 will play out, it's on us business leaders to help our workforce with the right tools and resources to sustain the situation and face the challenge. It is being recommended that changing performance management philosophy to align with this change and adopting performance management for new normal is critical for organizations in order to succeed.

\section{References}

Balani, A. (2020). Covid-19: What About The Appraisals?. Retrieved from: http://bwpeople. businessworld.in/article/Covid-19-What-About-TheAppraisals-/31-03-2020-187762/ (Accessed: April 2020)

Cascio,W.F. (2000). Managing a Virtual Workplace. Academy of Management Perspectives. 14(3), 81-90.

CBDT to link Field Officers Appraisals. Postings with Vivad se Vishwas. Retrieved from: https://economictimes. indiatimes.com/news/economy/policy/cbdt-to-linkfield-officers-annual-appraisals-postings-with-vivadse-vishwas-mop-ups/articleshow/74426727.cms (Accessed: April 2020)

Chatterjee, S. (2020). The Impact of Covid-19 on Performance Appraisals. Retrieved from: https://blog. darwinbox.com/performance-management/impact-ofcovid-19-on-performance-appraisals (Accessed: April 2020).

Clark, T. (2020). 8 Ways to Manage Your Team While Social Distancing. Retrieved from: https://hbr. org/2020/03/8-ways-to-manage-your-team-whilesocial-distancing (Accessed: April 2020).

Covid-19 effect: Reliance Industries to Cut Pay, Defer Bonuses for Hydrocarbon Biz Staff. Retrieved from: https://www.msn.com/en-in/money/topstories/ covid-19-effect-reliance-industries-to-cut-paydefer-bonuses-for-hydrocarbon-biz-staff/arBB13rJcB?ocid=spartandhp (Accessed: April 2020)

Gill, P. (2020). Here's What You Can Expect from TCS, Infosys. Wipro and peers this quarter. Retrieved from: https://www.businessinsider.in/business/corporates/ news/heres-what-you-can-expect-from-tcs-infosyswipro-and-peers-this-quarter/articleshow/75151878. cms (Accessed: April 2020) 
Guy, M. E. (2020). To Catch the Sparrow that has Flown. Journal of Public Affairs Education, 1-12.

Hemida, M. G., Abduallah, M. (2020). The SARS-CoV-2 outbreak from a one health perspective. One Health, 100127.

Gupta, A. (2020). Lockdown Impact: Reliance Industries Announces $10-50 \%$ Pay Cut, Mukesh Ambani to Forego Entire Salary. Retrieved from: https://www. msn.com/en-in/money/topstories/lockdown-impactreliance-industries-announces-10-50percent-paycut-mukesh-ambani-to-forego-entire-salary/arBB13qqEJ?ocid=spartandhp (Accessed: April 2020)

Mayer, K. (2020). HRE's Number of the Day: Employee Flexibility. Retrieved from: https://hrexecutive. com/hres-number-of-the-day-employee-flexibility/ (Accessed: April 2020)

McIlvaine, A. (2020). Performance Management in the Time of Corona Virus. Retrieved from: https://hrexecutive. com/performance-management-in-the-time-of-coronavirus/ (Accessed: April 2020)

Accenture (2020). Outmaneuver Uncertainty: Navigating the Human and Business Impact of Covid-19. Retrieved from: https://www.accenture.com/in-en/ about/company/coronavirus-business-economicimpact (Accessed: April 2020)
Juneja, P., Performance Appraisal. Retrieved from: https:// www.managementstudyguide.com/performance-appraisal.html (Accessed: April 2020)

Peshawaria, R. (2020). Performance Management in the Age of Social Distancing. Retrieved from: https://www. forbes.com/sites/rajeevpeshawaria/2020/04/04/ performance-management-in-the-age-of-socialdistancing/amp/ (Accessed: April 2020)

Upadhyay, J. (2020). Big-4 firms Defer Promotions, Appraisals, Bonuses and Salaries Amid Virus Crisis. Retrieved from: https://www.livemint.com/ companies/news/big-4-firms-defer-promotionsappraisals-bonuses-and-salaries-amid-viruscrisis-1 1585505169035.html (Accessed: April 2020)

Verbeemen, E., D' Amico, S. (2020). Why Remote Working will be the New Normal, Even After Covid-19. Retrieved from: https://www.ey.com/en_be/covid-19/ why-remote-working-will-be-the-new-normal-evenafter-covid-19 (Accessed: April 2020)

Wilken, H., Managing performance evaluations during a pandemic. Retrieved from: https://www.cultureamp. $\mathrm{com} / \mathrm{blog} / \mathrm{managing-performance-evaluations-}$ during-a-pandemic/ (Accessed: April 2020)

\section{堵 \\ CHITKARA \\ UNIVERSITY}

Journal of Technology Management for Growing Economies

Chitkara University, Saraswati Kendra, SCO 160-161, Sector 9-C, Chandigarh, 160009, India

\section{Volume -11, Issue-1}

April 2020

ISSN 2456-3226

Copyright: [C 2020 Nitika Kaushik and Poonam Arora] This is an Open Access article published in Journal of Technology Management for Growing Economies by Chitkara University Publications. It is published with a Creative Commons Attribution- CC-BY 4.0 International License. This license permits unrestricted use, distribution, and reproduction in any medium, provided the original author and source are credited. 